\title{
Prostatic Tissue
}

National Cancer Institute

\section{Source}

National Cancer Institute. Prostatic Tissue. NCI Thesaurus. Code C33414.

Tissue composed of tubuloalveolar glands embedded in fibromuscular stroma. The stroma is smooth muscle separated by strands of connective tissue rich in collagenous and elastic fibers. The secretory alveoli of the prostate are irregularly shaped with papillary projections of the mucosa into the lumen of the gland. 